\title{
PEMODELAN SISTEM PENUNJANG KEPUTUSAN PEMILIHAN GURU TERBAIK SMA YP-BDN MENGGUNAKAN AHP DAN SAW
}

\author{
Joko Wijayanto ${ }^{1}$, Safitri Juanita ${ }^{2}$ \\ ${ }^{1,2}$ Fakultas Teknologi Informasi, Sistem Informasi, Universitas Budi Luhur, Jakarta, Indonesia \\ Email: ${ }^{1}$ ssingo2@gmail.com, ${ }^{2 *}$ safitri.juanita@budiluhur.ac.id \\ (*: corresponding author)
}

\begin{abstract}
Abstrak-Sekolah SMA YP-BDN memiliki kegiatan pemilihan guru terbaik yang diadakan setahun sekali dan hanya didasarkan pada presensi kehadiran guru, sehingga menimbulkan konflik kepentingan dalam pengambilan keputusan. Dari permasalahan tersebut, maka Kepala Sekolah membuat kriteria tambahan untuk pemilihan guru terbaik yaitu tugas tambahan, dan poin pelanggaran. Namun untuk menghindari konflik kepentingan maka diperlukan Sistem Pendukung Keputusan (SPK) yang membantu kepala sekolah dan jajaran dalam mengoptimalkan proses pemilihan guru terbaik sehingga penelitian ini melakukan pemodelan SPK berbasis desktop untuk mengimplementasikan metode Analytical Hierarchy Process (AHP) dan Simple Additive Weighting (SAW). Metode AHP digunakan untuk menentukan bobot dari kriteria yang dipakai untuk penilaian guru terbaik. Sedangkan metode SAW digunakan untuk menentukan peringkat guru. Aplikasi dibuat menggunakan Microsoft Visual Studio 2008 dan basis data MYSQL. Tujuan penelitian ini adalah menerapkan metode AHP dan SAW pada aplikasi SPK untuk memberikan rekomendasi bagi kepala sekolah dalam proses pengambilan keputusan pemilihan guru terbaik pada SMA YP-BDN. Kesimpulan dari penelitian ini adalah berdasarkan proses pembobotan menggunakan metode AHP maka hasil pembobotan 3 kriteria adalah: presensi 0.6734 , tugas tambahan 0.0618 , dan poin pelanggaran 0.2648 . Nilai bobot kemudian digunakan sebagai proses perhitungan pada metode SAW sehingga menampilkan dan mengurutkan nilai guru berdasarkan peringkat terbesar ke terkecil. SPK pemilihan guru terbaik dengan metode AHP dan SAW terbukti membantu SMA YP-BDN dengan memberikan rekomendasi bagi kepala sekolah dalam mengambil keputusan guru terbaik dengan cepat dan tepat serta mempermudah pihak sekolah dalam menyimpan administrasi proses pemilihan guru terbaik sehingga mempermudah proses audit administrasi sekolah saat dibutuhkan.
\end{abstract}

Kata Kunci: Sistem Penunjang Keputusan, Pemilihan Guru Terbaik, AHP, SAW, SMA YP-BDN

\begin{abstract}
YP-BDN Senior High School has the best teacher selection activity which is held once a year and is only based on the presence of teachers, thus creating a conflict of interest in decision making. From these problems, the Principal made additional criteria for selecting the best teachers, namely additional assignments and points of the violation. However, to avoid conflicts of interest, a Decision Support System (DSS) is needed which helps principals and staff in optimizing the process of selecting the best teachers so that this study carries out desktop-based DSS modeling to implement Analytical Hierarchy Process (AHP) and Simple Additive Weighting (SAW) methods. The AHP method is used to determine the weight of the criteria used for the best teacher assessment. While the SAW method is used to determine teacher rankings. Applications created using Microsoft Visual Studio 2008 and MYSQL database. The purpose of this study was to apply the AHP and SAW methods to the DSS application to provide recommendations for principals in the decision-making process for selecting the best teachers at SMA YP-BDN. The conclusion of this study is that based on the weighting process using the AHP method, the results of the 3 criteria weighting are: presence 0.6734, additional assignment 0.0618, and violation points 0.2648. The weight value is then used as a calculation process in the SAW method so that it displays and ranks teacher grades based on the largest to the smallest rank. DSS for the selection of the best teachers using the AHP and SAW methods has been proven to help SMA YP-BDN by providing recommendations for the principal in making the best teacher decisions quickly and accurately and making it easier for schools to keep the administration of the best teacher selection process so that it makes the school administration audit process easier when needed.
\end{abstract}

Keywords: Decision Support System, Best Teacher Selection, AHP, SAW, SMA YP-BDN

\section{PENDAhuluan}

Menurut penelitian [1] Hasil keputusan yang rasional adalah keputusan yang diambil dengan menggunakan pendekatan perilaku organisasi, yang dimaksud dengan rasionalisasi adalah kesesuaian antara rencana dengan tujuan yang telah disusun. Sekolah SMA YP-BDN saat ini melakukan penilaian guru terbaik dengan tujuan untuk evaluasi tugas, peran dan tanggungjawab guru. Kriteria yang digunakan saat pemilihan guru terbaik adalah presensi kehadiran guru, tentu hal ini membuat proses pengambilan keputusan guru terbaik kurang rasional karena tidak sesuai dengan tujuannya yaitu evaluasi tugas, peran dan tanggungjawab guru. Sehingga kepala sekolah menambahkan 2(dua) kriteria untuk penilaian guru terbaik, yaitu tugas tambahan, dan poin pelanggaran. Saat ini proses pengambilan keputusan guru terbaik masih menggunakan proses administasi pembukuan sehingga menimbulkan masalah yaitu: belum terdapat metode yang digunakan untuk pembobotan nilai dalam pemilihan guru terbaik, Kurang objektif dalam menentukan guru terbaik, dikarenakan pengambilan keputusan belum didukung proses seleksi yang teradministrasi dengan baik, Pengolahan data lambat karena proses penilaian masih dilakukan secara manual. Maka untuk 
mengoptimalkan proses pemilihan guru terbaik, pada penelitian ini akan dilakukan eksperimen untuk membuat sistem penunjang keputusan pemilihan guru terbaik pada SMA YP-BDN menggunakan metode AHP dan SAW.

Penerapan metode Analytical Hierarchy Process (AHP) sebagai solusi dalam memberikan bobot pada kriteria yang akan digunakan sebagai pengambilan keputusan sudah banyak dilakukan oleh penelitian sebelumnya, diantaranya penelitian yang dilakukan oleh [2] yang melakukan pemilihan guru terbaik pada SMPN 161 Jakarta menggunakan 6 kriteria yaitu pengetahuan pekerjaan, kemampuan komunikasi, motivasi, kehadiran, kejujuran, tanggung jawab, dengan menggunakan metode AHP maka diketahui bobot pengetahuan pekerjaan 0.0909, kemampuan komunikasi 0.1604, motivasi 0.1148, Kehadiran 0.2015, Kejujuran 0.2355, Tanggung Jawab 0.1969. Penelitian lainnya dilakukan oleh [3] yang melakukan penelitian pemilihan karyawan terbaik pada PT.Radio Elshinta dan menggunakan metode AHP untuk menghitung bobot kriteria dan subkriteria Personal skill karyawan, hasil penelitian menunjukkan bobot subkriteria dan kriteria dalam bentuk presentasi sebagai berikut: subkriteria Kreativitas dan inisiatif serta fleksibilitas 3,87\%, kemampuan berfikir secara rasional dan kemauan untuk maju 28,78\%, Disiplin kerja dan rasa tanggung jawab dalam melaksanakan tugas 17,52\%, kemampuan berkomunikasi dan bekerja sama $8,52 \%$, Kerajinan, ketekunan, kerapihan, kejujuran, \& loyal dalam melaksanakan pekerjaan 17,59\%, Kedewasaan, hormat kepada atasan dan stabilitas 8,7\%, Rasa memiliki perusahaan 15,01\%. Penelitian lainnya [4] menggunakan metode AHP untuk menghitung bobot pemilihan siswa terbaik pada sekolah umum surya bangsa palem semi menggunakan sembilan kriteria, yaitu Kedisplinan dan Tanggung Jawab, Kebersihan dan Kerapihan, Kerjasama, Kesopanan, Kemandirian, Kerajinan. Kejujuran, Kepemimpinan dan Ketaatan. Hasil penelitian ini terdapat tiga kriteria yang paling menentukan yaitu kejujuran dengan bobot 0.2131 , kerajinan dengan bobot 0.1302 , dan kesopanan dengan bobot 0.1232. Penerapan metode Simple Additive Weighting (SAW) sebagai proses perangkingan dalam sistem pendukung keputusan juga sudah banyak digunakan oleh penelitian-penelitian sebelumnya, diantaranya penelitian yang dilakukan oleh [5] menggunakan metode AHP dan SAW untuk penentuan guru terbaik di SMPN 10 Tangerang, hasil penelitian menunjukkan nilai tertinggi sebesar 3.6859 dari 5 orang guru yang dinilai. Penelitian lainnya [6] SPK pemilihan karyawan terbaik pada PT.Telkom Indonesia, Tbk, menggunakan metode Simple Additive Weighting (SAW) untuk proses perangkingan karyawan terbaik dimana nilai tertinggi adalah 0,9846.

Berdasarkan penelitian-penelitian sebelumnya maka dapat disimpulkan bahwa metode AHP dapat digunakan sebagai metode untuk mencari bobot pada tiap kriteria dan metode SAW dapat digunakan sebagai metode untuk perangkingan. sehingga pada penelitian ini akan dipakai kedua metode tersebut untuk diimplementasikan di sistem penunjang keputusan pemilihan guru terbaik pada SMA YP-BDN dengan menggunakan 3 kriteria yaitu presensi, tugas tambahan dan poin pelanggaran. Tujuan dari penelitian ini adalah membuat SPK yang dapat memberikan rekomendasi bagi kepala sekolah dalam membuat keputusan pemilihan guru terbaik pada SMA YP-BDN sehingga proses pengambilan keputusan dapat lebih cepat dan teradministrasi dengan baik.

\section{METODE PENELITIAN}

\subsection{Tahapan Penelitian}

Tahapan penelitian yang akan dilakukan ada di Error! Reference source not found.

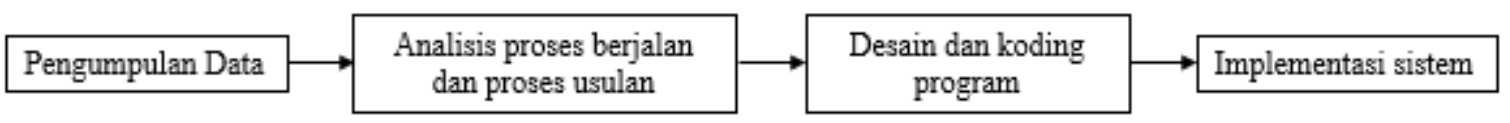

Gambar 1. Tahapan Penelitian Pemodelan Sistem Penunjang Keputusan pemilihan Guru terbaik pada SMA YP-BDN

Tahapan penelitian adalah sebagai berikut: (1) Pengumpulan Data [7]: pada tahap ini akan dilakukan proses pengumpulan data yaitu wawancara kepada kepala sekolah, observasi ke tempat riset, analisis dokumen (daftar nama guru, pembagian tugas guru, rekapitulasi absensi (presensi), daftar tugas praktek/tambahan, daftar pelanggaran guru, surat keterangan persetujuan kriteria,surat keterangan persetujuan konversi kriteria, kuesioner bobot kriteria), dan studi literatur. (2) Analisis proses berjalan dan proses usulan adalah pada tahap ini akan dilakukan analisis proses yang sudah berjalan ah menggunakan data-data yang sudah dikumpulkan pada proses pengumpulan data, proses ini untuk memahami lebih dalam proses bisnis pengambilan keputusan pemilihan guru terbaik, kemudian mengambarkan proses usulan sebagai inti dari penelitian ini yaitu mengembangkan pemodelan sistem penunjang keputusan pemilihan guru terbaik pada SMA YP-BDN. Proses usulan digambarkan menggunakan diagram aktivitas, use case diagram. (3) Desain dan koding program [8], pada tahap ini akan dilakukan desain basis data dengan ER-D dan pembuatan aplikasi SPK dengan melakukan koding program menggunakan perangkat lunak Microsoft Visual Studio 2008 dan basis data MYSQL. (4) Implementasi sistem, pada tahap ini akan dilakukan implementasi sistem dengan melakukan uji coba data guru yang ada di sekolah SMA YP-BDN kemudian mencetak hasil pengolahan data berupa rekomendasi 
Available online at http://jom.fti.budiluhur.ac.id/index.php/IDEALIS/index

keputusan pemilihan guru terbaik yang akan digunakan oleh kepala sekolah sebagai salah satu dokumentasi untuk mengambil keputusan.

\section{HASIL DAN PEMBAHASAN}

\subsection{Proses Bisnis Usulan}

Pada tahap ini akan dibahas proses bisnis usulan pemodelan SPK pemilihan guru terbaik pada SMA YP-BDN.

a. Proses Entry Master

Proses Entry Master adalah proses untuk menginput data guru, kriteria pengambilan keputusan guru terbaik dan rekapitulasi presensi (absensi) guru. Tahapan proses ini adalah: Tata usaha akan menginput semua data terbaru pada guru dan kriteria pengambilan keputusan guru terbaik dimana kedua input ini akan disimpan ke tabel master. Kemudian Tata usaha akan menginput rekapitulasi presensi kehadiran guru (absensi).

b. Proses Transaksi

Proses transaksi adalah proses untuk pengolahan data nilai guru berdasarkan kriteria presensi, tugas tambahan dan poin pelanggaran. keluaran dari proses ini adalah surat keputusan yang berisi rekomendasi guru terbaik. Tahapan proses ini adalah: setiap bulan Tata usaha melakukan proses penilaian yang diawali dengan Tata usaha meminta kuesioner perbandingan kriteria kepada kepala sekolah kemudian Tata usaha menginput data kuesioner tersebut ke aplikasi SPK, setelah data perbandingan kriteria diinput kemudian Tata usaha menginput data penilaian yang berisi data kandidiat guru terbaik dengan nilai kriteria yaitu nilai presensi (absensi), tugas tambahan dan poin pelanggaran (ini disebut dengan nilai alternatif). Jika semua data kandidat guru terbaik sudah diinput maka aplikasi SPK akan memproses data penilaian guru dan menghasilkan keluaran berupa surat keputusan (rekomendasi) guru terbaik, namun jika Tata usaha menambah kandidat guru maka Tata usaha harus menginput kembali data nilai alternatif baru ke aplikasi SPK kemudian aplikasi akan melakukan proses pengolahan nilai tersebut yang menghasilkan keluaran berupa surat keputusan (rekomendasi) guru terbaik. Proses ini digambarkan menggunakan diagram aktivitas pada Gambar 2. c. Proses Pembuatan Laporan

Proses pembuatan laporan adalah proses aplikasi SPK pemilihan guru terbaik pada SMA YP-BDN untuk menampilkan keluaran proses berupa laporan yang akan dibuat setiap bulan. Pada proses ini, Tata usaha dapat mencetak semua laporan yaitu cetak laporan ranking guru, cetak laporan hasil keputusan, cetak laporan kinerja guru untuk diserahkan kepada kepala sekolah.

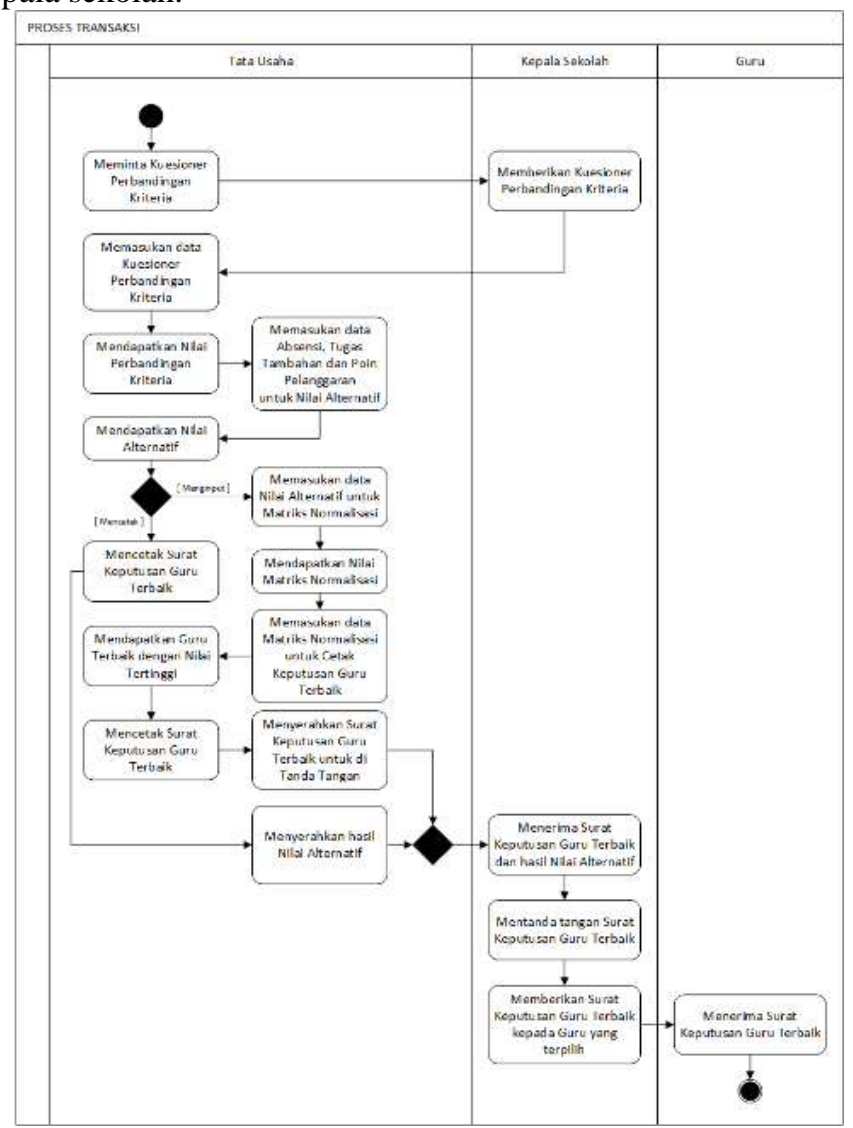

Gambar 2. Proses Transaksi Pada Pemodelan Sistem Penunjang Keputusan Pemilihan Guru Terbaik Pada SMA YP-BDN 


\subsection{Rancangan Basis Data}

Proses analisis rancangan basis data untuk pemodelan SPK pemilihan Guru terbaik pada SMA YP-BDN dimulai dari perancangan ER-D yang kemudian ditransformasi menjadi LRS terdapat pada Gambar 3. Berdasarkan hasil analisis, maka pada penelitian ini akan digunakan 8 entitas atau tabel.

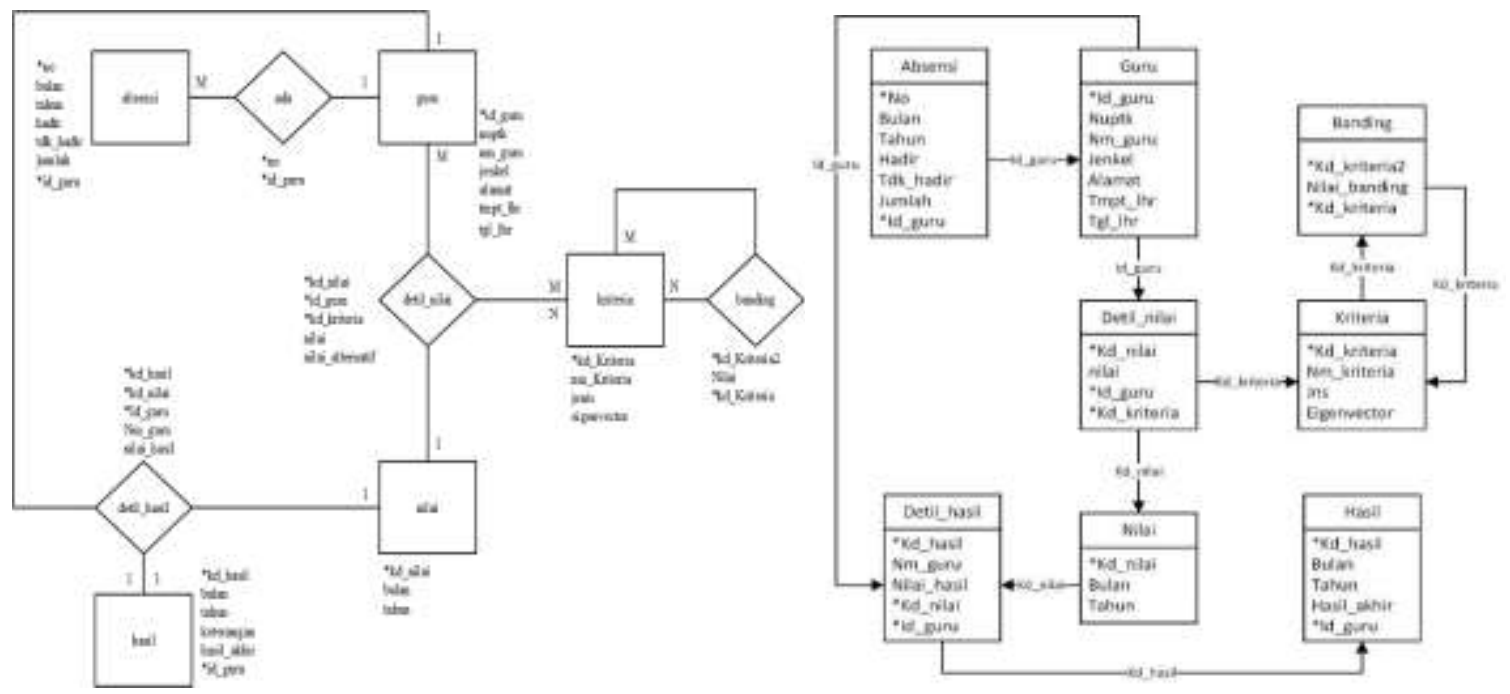

Gambar 3. ERD - LRS untuk Pemodelan Sistem Penunjang Keputusan pemilihan Guru terbaik pada SMA YP-BDN

\subsection{Struktur Tampilan}

Struktur tampilan Sistem Penunjang Keputusan pemilihan Guru terbaik pada SMA YP-BDN ditunjukan pada Gambar 4:

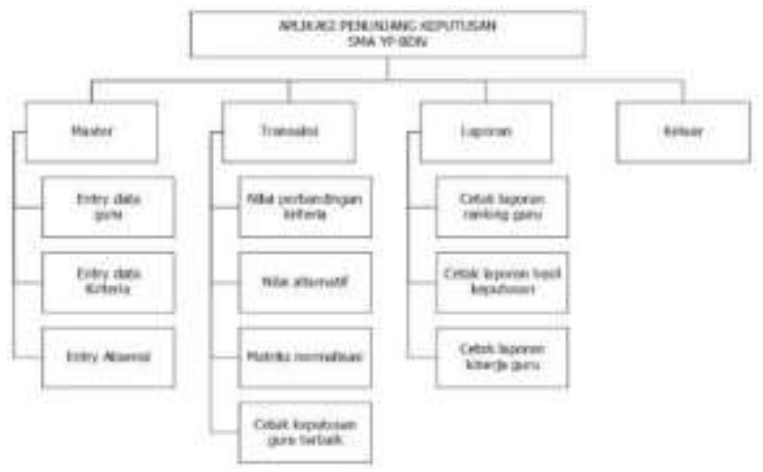

Gambar 4. Struktur Tampilan Pemodelan Sistem Penunjang Keputusan pemilihan Guru terbaik pada SMA YP-BDN

\subsection{Implementasi Metode AHP dan SAW}

\section{a. Implementasi Metode AHP}

AHP dikembangkan oleh Thomas L. Saaty, ahli matematika dari Universitas Pitssburg, Amerika Serikat pada tahun 1970-an. Model penunjang keputusan ini untuk menguraikan suatu masalah multi faktor atau multi kriteria yang kompleks sehingga menjadi sebuah hierarki [9]. Untuk itu diperlukan penentuan struktur hirarki kriteria dan alternatif yang ada di Gambar 5. Struktur hirarki pada Gambar 5 akan digunakan pada Pemodelan Sistem Penunjang Keputusan pemilihan Guru terbaik pada SMA YP-BDN. 
Available online at http://jom.fti.budiluhur.ac.id/index.php/IDEALIS/index

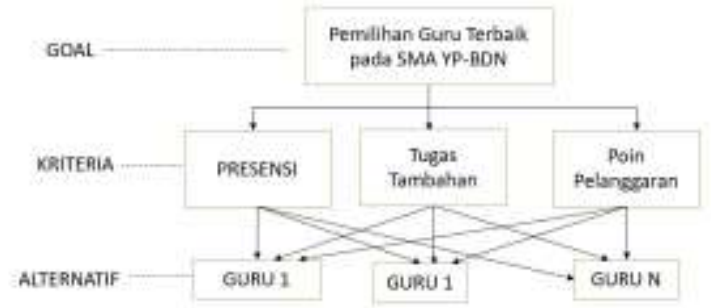

Gambar 5. Struktur Hierarki Sistem Penunjang Keputusan pemilihan Guru terbaik pada SMA YP-BDN

Berikut langkah-langkah yang dilakukan dalam pengolahan data dengan metode Analytical Hierarchy Process (AHP):

1) Menentukan nilai perbandingan kepentingan antar kriteria

Berikut adalah kriteria yang digunakan sebagai dasar pemilihan guru terbaik pada SMA YP-BDN:

- Presensi 9 (sembilan) kali lebih penting dari tugas tambahan.

- Presensi 3 (tiga) kali lebih penting dari poin pelanggaran.

- Poin pelanggaran 5 (Iima) kali lebih penting dari tugas tambahan.

2) Perbandingan Kepentingan antar Kriteria

Berdasarkan perbandingan kepentingan didapat dari hasil wawancara, maka digambarkan pada tabel matriks perbandingan per-kriteria yang terdapat pada Tabel 1.

Tabel 1. Matriks Perbandingan Per Kriteria

\begin{tabular}{cccc}
\hline Kriteria & Presensi & Tugas Tambahan & Poin Pelanggaran \\
\hline 1: Presensi & 1 & 9 & 3 \\
2: Tugas Tambahan & $1 / 9$ & 1 & $1 / 5$ \\
3: Poin Pelanggaran & $1 / 3$ & 5 & 1 \\
\hline
\end{tabular}

Langkah-Iangkah dalam menentukan bobot masing-masing kriteria dengan model AHP (Analytical Hierarchy Process) adalah sebagai berikut:

- Langkah 1

Menjabarkan matriks pada Tabel 1 ke dalam bentuk desimal yang ditampilkan pada Tabel 2 .

Tabel 2. Matriks Perbandingan PerKriteria dalam bentuk desimal

\begin{tabular}{cccc}
\hline Kriteria & Presensi & Tugas Tambahan & Poin Pelanggaran \\
\hline 1 & 1,0000 & 9,0000 & 3,0000 \\
2 & 0,1111 & 1,0000 & 0,2000 \\
3 & 0,3333 & 5,0000 & 1,0000
\end{tabular}

- $\quad$ Langkah 2

Tabel 3 menampilkan proses perkalian 2 matriks yang sama.

Tabel 3. Perkalian Matriks Kriteria

\begin{tabular}{cccccccc}
\hline Kriteria & Presensi & Tugas Tambahan & Poin Pelanggaran & X & Presensi & Tugas Tambahan & Poin Pelanggaran \\
\hline 1 & 1,0000 & 9,0000 & 3,0000 & $\mathbf{X}$ & 1,0000 & 9,0000 & 3,0000 \\
2 & 0,1111 & 1,0000 & 0,2000 & $\mathbf{X}$ & 0,1111 & 1,0000 & 0,2000 \\
3 & 0,3333 & 5,0000 & 1,0000 & $\mathbf{X}$ & 0,3333 & 5,0000 & 1,0000
\end{tabular}

- Langkah 3

Tabel 4 menampilkan hasil dari perkalian matriks dan menjumlahkan tiap-tiap baris hasil dari perkalian matriks.

Tabel 4. Hasil perkalian matriks dan penjumlahan tiap baris dari perkalian matriks

\begin{tabular}{ccccc}
\hline Kriteria & Presensi & Tugas Tambahan & Poin Pelanggaran & Jumlahkan \\
\hline 1 & 2.9999 & 33.0000 & 7.8000 & 43.7999 \\
2 & 0.2888 & 2.9999 & 0.7333 & 4.0220 \\
3 & 1.2221 & 12.9997 & 2.9999 & 17.2217 \\
\hline
\end{tabular}

- Langkah 4 
Available online at http://jom.fti.budiluhur.ac.id/index.php/IDEALIS/index

Menormalisasikan dengan membagi hasil penjumlahan tiap kriteria dengan total penjumlahan. Proses ini menghasilkan eigenvector yang ditampilkan pada Tabel 5.

Tabel 5. Hasil Eigenvector

\begin{tabular}{ccc}
\hline Kriteria & Hasil Penjumlahan & Pembagian \\
\hline 1 & 43.7999 & $\mathbf{0 . 6 7 3 4}$ \\
2 & 4.0220 & $\mathbf{0 . 0 6 1 8}$ \\
3 & 17.2217 & $\mathbf{0 . 2 6 4 8}$ \\
\hline & $\mathbf{6 5 . 0 4 3 6}$ & 1
\end{tabular}

- $\quad$ Langkah 5

Berdasarkan Tabel 5 maka dapat diketahui nilai bobot dari masing-masing kriteria yang diambil dari eigenvector. Presensi memiliki nilai bobot 0.6734 , tugas tambahan nilai bobot 0.0618 dan poin pelanggaran nilai bobot 0.2648.

\section{b. Implementasi Metode SAW}

Metode SAW yang juga dikenal dengan istilah metode penjumlahan pembobotan. Konsep dasar dari Simple Additive Weighting adalah pencari penjumlahan terbobot dari suatu rating kinerja pada setiap alternative pada semua atribut [10]. Berikut adalah langkah-langkah yang akan dilakukan saat implementasi metode SAW pada Sistem Penunjang Keputusan pemilihan Guru terbaik pada SMA YP-BDN.

1. Matriks Normalisasi

Berdasarkan banyaknya guru pada SMA YP-BDN maka pada pengujian hanya akan diambil 3 (tiga) guru sebagai contoh penerapan dengan metode Simple Additive Weighting (SAW) dan dalam hal lni kriteria poin pelanggaran yang bernilai 0 (nol) sudah dikonversi menjadi 1 (satu) untuk menghindari hasil tak terhingga. Tabel 6 adalah nilai alternatif tiap kriteria dari 3 guru dan Tabel 7 adalah presentasi bobot kriteria yang dihasilkan dari implementasi metode AHP.

Tabel 6. Nilai Alternatif Per-Kriteria

\begin{tabular}{lccc}
\hline \multirow{2}{*}{ Alternatif } & \multicolumn{3}{c}{ Kriteria } \\
\cline { 2 - 4 } & Presensi & Tugas Tambahan & Poin Pelanggaran \\
\hline Dwi Roby, S.Pd & 96 & 4 & 2 \\
Ira Wijaya Piliang, S.Pd.I & 100 & 2 & 3 \\
Mochamad Nasri, S.Pd & 100 & 1 & 2
\end{tabular}

Tabel 7. Persentase Bobot Kriteria

\begin{tabular}{lll}
\hline Kode Kriteria & Nama Kriteria & Bobot \\
\hline Kr01 & Presensi & $67,34 \%$ \\
Kr02 & Tugas Tambahan & $6,18 \%$ \\
Kr03 & Poin Pelanggaran & $26,48 \%$ \\
& Total Bobot & $\mathbf{1 0 0 \%}$ \\
\hline
\end{tabular}

Pertama matriks di normalisasi dengan dihitung nilai tiap kriteria, lalu menghitung kriteria biaya (cost) dan kriteria keuntungan (benefit) dengan persamaan berikut:

$$
r_{i j}=\left\{\begin{array}{l}
\frac{X_{I J}}{\operatorname{Max}_{i} X_{i j}} \\
\frac{\operatorname{Min}_{i} X_{i j}}{X_{i j}}
\end{array}\right.
$$

Jika $\mathrm{j}$ adalah atribut keuntungan (benefit) dan jika $\mathrm{j}$ adalah biaya (cost)

Keterangan:

$\mathrm{r}_{\mathrm{ij}}=$ nilai rating kinerja ternormalisasi

$\mathrm{X}_{\mathrm{ij}}=$ nilai atribut yang dimiliki dari setiap kriteria

$\operatorname{Max}_{\mathrm{i}} \mathrm{X}_{\mathrm{ij}}=$ nilai terbesar alternatif dari setiap kriteria $\mathrm{i}$

$\operatorname{Min}_{\mathrm{i}} \mathrm{X}_{\mathrm{ij}}=$ nilai terkecil alternatif dari setiap kriteria $\mathrm{i}$

Benefit $=$ Jika nilai terbesar yang terbaik

Cost $=$ Jika nilai terkecil ada terbaik

Pada penelitian ini terdapat penggolongan kriteria benefit dan cost terdapat pada Tabel 9.

Tabel 8. Penggolongan Kriteria berdasarkan Benefit dan Cost 
Available online at http://jom.fti.budiluhur.ac.id/index.php/IDEALIS/index

\begin{tabular}{lcc}
\hline Nama Kriteria & Benefit & Cost \\
\hline & & \\
\hline Presensi & $\sqrt{ }$ & \\
Tugas Tambahan & $\sqrt{ }$ & \\
Poin Pelanggaran & & $\sqrt{ }$ \\
\hline
\end{tabular}

Selanjutnya 3 (tiga) kriteria dihitung menggunakan rumus sesuai dengan penggolongan kriteria sehingga menghasilkan nilai seperti di bawah ini.

- Perhitungan Presensi

Dwi $=\frac{96}{\max (96 ; 100 ; 100)}=\frac{96}{100}=0.96 \quad \operatorname{Ira}=\frac{100}{\max (96 ; 100 ; 100)}=\frac{100}{100}=1 \quad$ Nasri $=\frac{100}{\max (96 ; 100 ; 100)}=\frac{100}{100}=1$

- Perhitungan Tugas tambahan

Dwi $=\frac{4}{\max (4 ; 2 ; 1)}=\frac{4}{4}=1 \quad \operatorname{Ira}=\frac{2}{\max (4 ; 2 ; 1)}=\frac{2}{4}=0.5 \quad$ Nasri $=\frac{1}{\max (4 ; 2 ; 1)}=\frac{1}{4}=0.25$

- Perhitungan Poin Pelanggaran

Dwi $=\frac{1}{\min (2 ; 3 ; 2)}=\frac{1}{2}=0.5 \quad \operatorname{Ira}=\frac{3}{\min (2 ; 3 ; 2)}=\frac{3}{3}=1 \quad$ Nasri $=\frac{1}{\min (2 ; 3 ; 2)}=\frac{1}{2}=0.5$

Hasil perhitungan matriks yang telah dinormalisasi per-kriteria di atas, dapat dilihat pada Tabel 9.

Tabel 9. Nilai Matriks Normalisasi

\begin{tabular}{lccc}
\hline \multirow{2}{*}{ Alternatif } & \multicolumn{3}{c}{ Kriteria } \\
\cline { 2 - 4 } & Presensi & Tugas Tambahan & Poin Pelanggaran \\
\hline Dwi Roby, S.Pd & 0.96 & 1.00 & 1.00 \\
Ira Wijaya Piliang, S.Pd.I & 1.00 & 0.50 & 0.25 \\
Mochamad Nasri, S.Pd & 0.50 & 1.00 & 0.50 \\
Bobot & 0,6734 & 0,0618 & 0,2648 \\
\hline
\end{tabular}

Dari Tabel 9, dilakukan perhitungan nilai guru per-kriteria dan bobot yang telah dihitung menggunakan metode AHP

Dwi Roby, S.Pd $=\{(0.96 \times 0.6734)+(1.00 \times 0.0618)+(1.00 \times 0.2648)\}=0.6464+0.0618+0.2648$

$$
=0.9731
$$

Ira Wijaya Piliang, S.Pd.I $=\{(1.00 \times 0,6734)+(0.50 \times 0.0618)+(0.25 \times 0.2648)\}$

$$
=0.6734+0.1236+0,0662=\mathbf{0 . 8 6 3 2}
$$

Mochamad Nasri, S.Pd $=\{(0.50 \times 0.6734)+(1.00 \times 0.0618)+(0.50 \times 0.2648)\}$

$$
=0.3367+0.0618+0.1324=\mathbf{0 . 5 3 0 9}
$$

Dari hasil perhitungan di atas didapatkan hasil sebagai berikut:

Ranking 1: Dwi Roby, S.Pd

Ranking 2: Ira Wijaya Piliang, S.Pd.I

Ranking 3: Mochamad Nasri, S.Pd

Sehingga dapat disimpulkan bahwa nilai terbesar diperoleh Dwi Roby, S.Pd sebagai alternatif terbaik dengan nilai 0.9731 .

\section{c. Implementasi Sistem}

1) Tampilan Halaman Utama Dan Entry Data Guru

Pada form ini terdapat Fitur input yang terdiri dari form entri data guru, form entri data kategori, form entri data presensi (absensi). Fitur proses yang terdiri dari form perbandingan kriteria, form nilai normalisasi, entri perhitungan nilai akhir, form cetak keputusan guru terbaik. Fitur laporan form laporan ranking guru, from laporan keputusan guru, form laporan kinerja guru. Berikut ini adalah tampilan menu utama dan form entry data guru yang ditunjukan pada Gambar 6. 
Available online at http://jom.fti.budiluhur.ac.id/index.php/IDEALIS/index

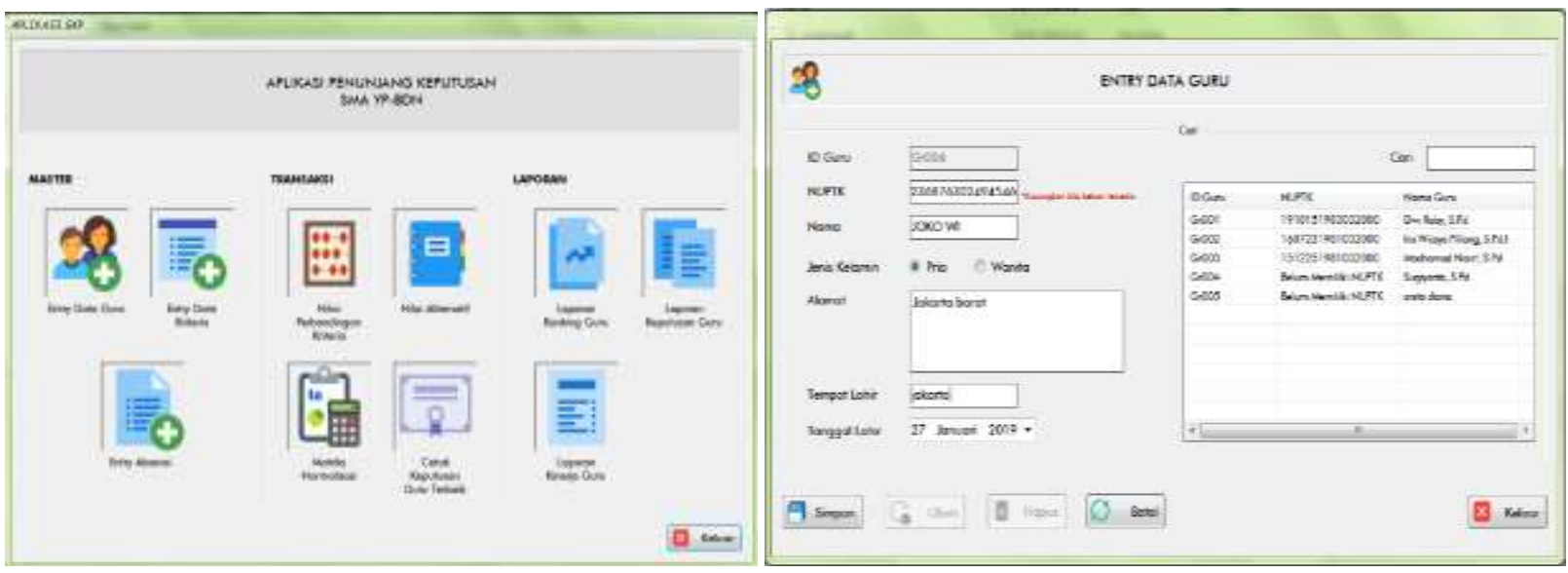

Gambar 6. Tampilan Menu Utama dan Form Entry Data Guru

2) Tampilan Form Entry Data Kriteria dan Presensi

Gambar 7 adalah tampilan form entry data kriteria dan entry presensi (absensi).
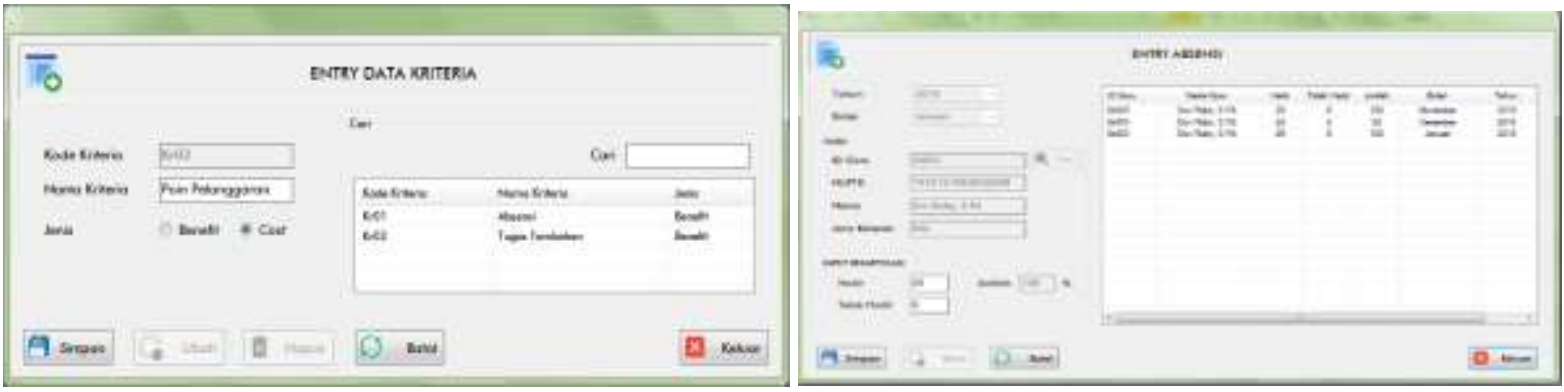

Gambar 7. Tampilan Form Entry Data Kriteria dan Form Entry Presensi

3) Tampilan Form Entry Nilai Perbandingan Kriteria dan Nilai Normalisasi Gambar 8 adalah tampilan form nilai perbandingan kriteria dan nilai normalisasi.
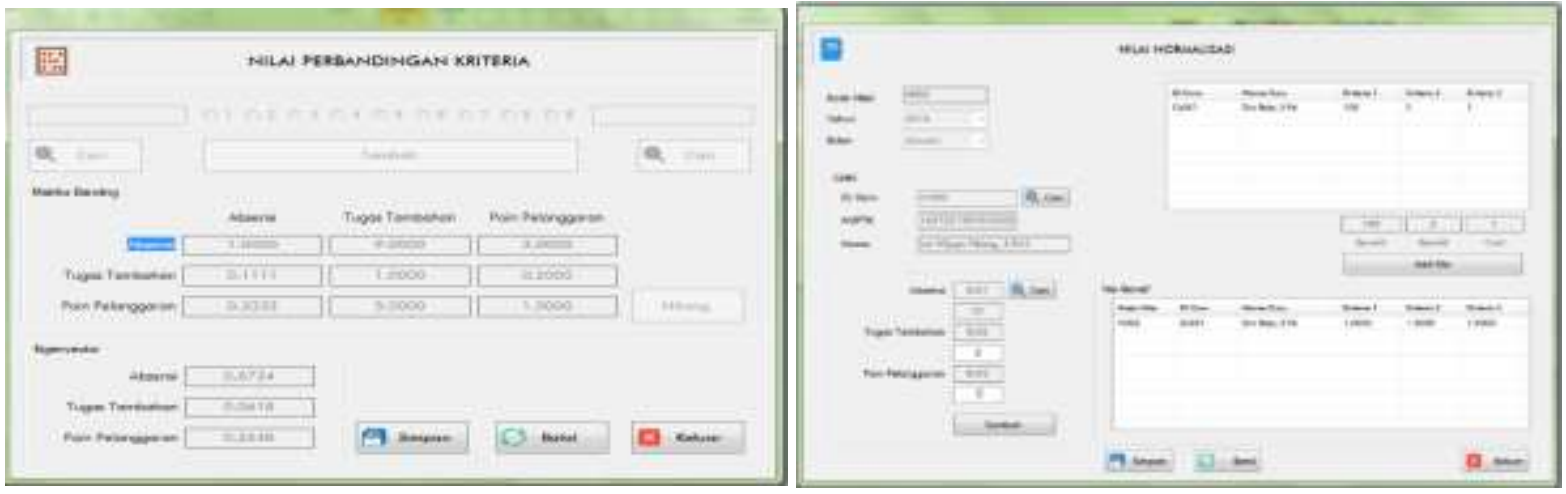

Gambar 8. Tampilan Form Entry Nilai Perbandingan Kriteria dan Nilai Normalisasi

4) Perhitungan Nilai Akhir

Gambar 9 adalah Tampilan Form Perhitungan Nilai Akhir dan Form Cetak Keputusan Guru Terbaik. 
Available online at http://jom.fti.budiluhur.ac.id/index.php/IDEALIS/index

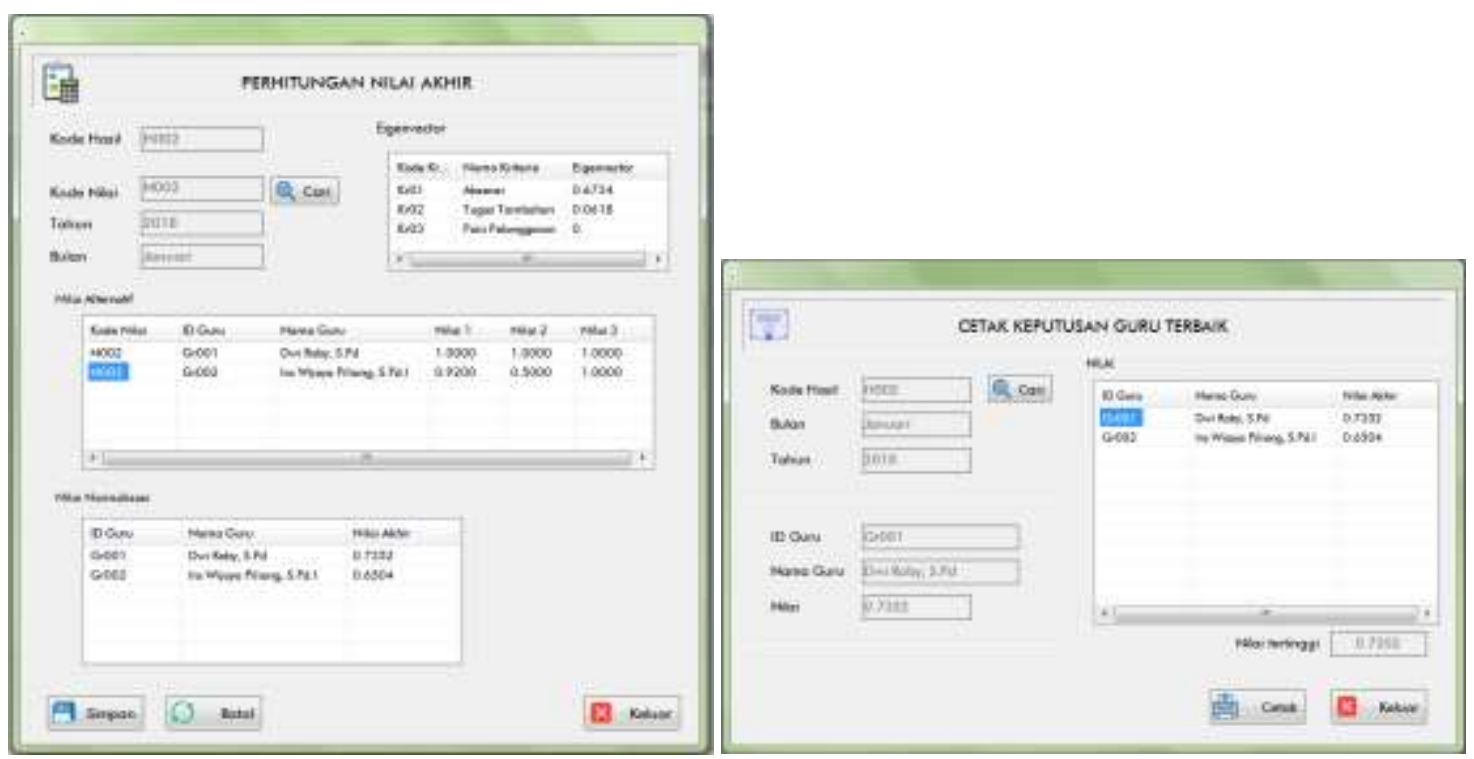

Gambar 9. Tampilan Form Perhitungan Nilai Akhir dan Form Cetak Keputusan Guru Terbaik

5) Cetak Keputusan Guru Terbaik

Gambar 10 adalah contoh keluaran aplikasi SPK yaitu Hasil Surat keputusan guru terbaik.

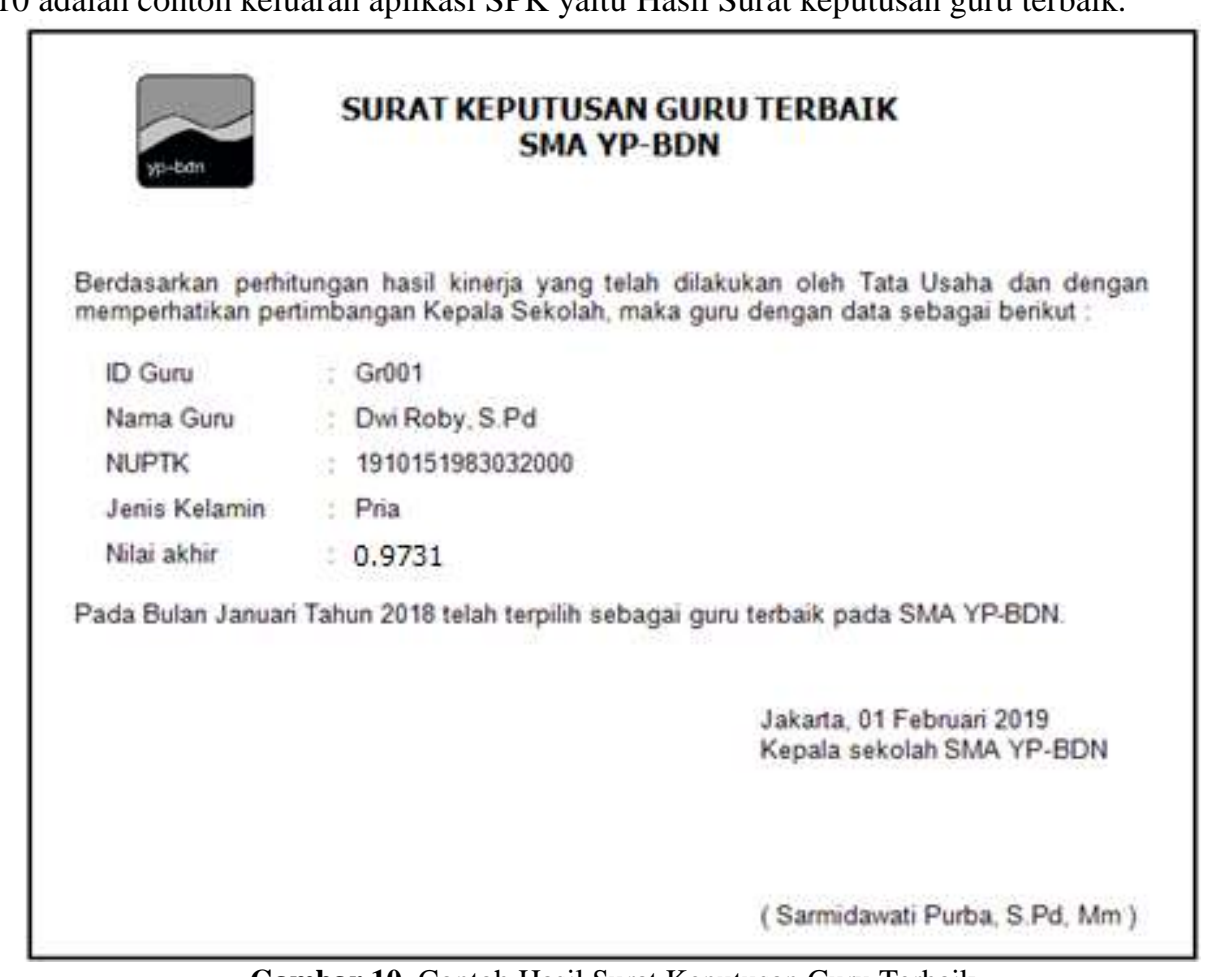

Gambar 10. Contoh Hasil Surat Keputusan Guru Terbaik

\section{KESIMPULAN}

Berdasarkan analisis yang telah dilakukan ada bab-bab sebelumnya, dapat disimpulkan beberapa hal yaitu dengan adanya metode Analytical Hierarchy Process (AHP) untuk penentuan bobot dari setiap kriteria dan adanya metode Simple Additive Weighting $(S A W)$ sebagai proses penilaian ranking guru. Data tersimpan dalam database sehingga mempermudah pihak sekolah dalam mengolah data.

\section{DAFTAR PUSTAKA}

[1] S. Suparno, "Peran Kepemimpinan Dalam Pengambilan Keputusan”, Mimb. Adm., vol. 6, no. 9, pp. 1-20, 2019. 
Available online at http://jom.fti.budiluhur.ac.id/index.php/IDEALIS/index

[2] M. I. Fadhilah and S. Juanita, "Penerapan Metode Analytical Hierarchy Process Dalam Sistem Pendukung Keputusan Pemilihan Guru Terbaik Studi Kasus SMPN 161 Jakarta", IDEALIS, vol. 2, no. 6, pp. 81-88, 2019.

[3] A. M. Pratama and Rusdah, "Penerapan Metode Analytical Hierarchy Process Untuk Pemilihan Karyawan Terbaik Pada PT. Radio ELSHINTA", IDEALIS, vol. 3, no. 1, pp. 386-391, 2020.

[4] S. Hanafi and R. Rusdah, "Penerapan Metode Analytical Hierarchy Process Untuk Pemilihan Siswa Terbaik Pada Sekolah Umum Surya Bangsa Palem Semi”, IDEALIS, vol. 2, no. 6, pp. 194-198, 2019.

[5] A. Prasetyo and L. Fajarita, "Penerapan Metode Analytical Hierarchy Process (AHP) Dan Simple Additive Weighting (SAW) Dalam Sistem Penunjang Keputusan Pemilihan Guru Terbaik pada SMPN 10 Tangerang”, IDEALIS, vol. 3, no. 2, pp. 2227, 2018.

[6] K. Hayyu and D. Mahdiana, "Sistem Penunjang Keputusan Dalam Pemilihan Karyawan Terbaik Pada PT Telkom Indonesia, Tbk Menggunakan Metode Analytical Hierarchy Process Dan Simple Additive Weighting”, IDEALIS, vol. 2, no. 6, pp. 456461, 2019.

[7] F. Wahid, "Metodologi Penelitian Sistem Informasi: Sebuah Gambaran Umum", Media Informatika, vol. 2, no. 1, pp. 69$81,2004$.

[8] A. Susanto and Meiryani, "System Development Method with The Prototype Method", in International Journal of Scientific \& Technology Research, 2019, vol. 8, no. 7, pp. 141-144.

[9] R. W. Saaty, "The analytic hierarchy process-what it is and how it is used", Math. Model., vol. 9, no. 3-5, pp. 161-176, 1987.

[10] A. Afshari, M. Mojahed, and R. M. Yusuff, "Simple Additive Weighting approach to Personnel Selection problem", International Journal Innovation Management Technology, vol. 1, no. 5, pp. 511-515, 2010. 